U.S. Department of Commerce - Frederick H. Mueller, Secretary National Bureau of Standards • A. V. Astin, Director

\title{
Protection Against Radiations From Sealed Gamma Sources
}

\author{
Recommendations of the \\ National Committee on Radiation Protection \\ and Measurements \\ NCRP Report No. 24
}

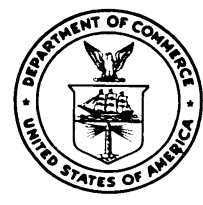

National Bureau of Standards Handbook 73

Issued July 27, 1960

[Supersedes H54]

For sale by the Superintendent of Documents, Washington 25, D.C. - Price 30 cents 